\title{
Explorations in Teaching Sustainable Design: A Studio Experience in Interior Design/Architecture
}

\author{
Meltem Ö. Gürel
}

\begin{abstract}
This article argues that a design studio can be a dynamic medium to explore the creative potential of the complexity of sustainability from its technological to social ends. The study seeks to determine the impact of an interior design/architecture studio experience that was initiated to teach diverse meanings of sustainability and to engage the participants with refined design applications that used sustainable choices. A teaching scheme that utilised a team of instructors with varying degrees of knowledge and competence in different aspects of the topic, mediated the education of both the students and the instructors themselves. The results were documented through observing the students and, later, a survey of the graduates. The study revealed that this studio experience developed a heightened awareness of sustainability as a multidimensional concept that requires critical thought processes, and greatly influenced the recognition of environmentally responsible design as an imperative in education. The findings also suggested that, ideally, sustainability should be addressed earlier, at lower levels, and needs to be woven into every aspect of a curriculum.
\end{abstract}


Introduction

'Spaceship Earth', our planet as popularised by Buckminster Fuller (1969), is a metaphor that comes to mind when considering the limitedness of the world's resources and the need to prioritise sustainability when shaping the built environment. As the portent of negative environmental changes has started to dawn on us, vigilance in sustainable practices has become more prevalent around the globe. Furthermore, the concept has reached a certain degree of maturity that has evoked critical outlooks in defining and applying sustainable design. Recognising the impact of the built environment in ecological and social problems and the accountability of architects and designers in responding to these, many professional organisations and academic programmes, especially those in more developed geographies, have initiated sustainable design education. This has brought up the question of how best to incorporate environmentally responsible design into the educational structure.

Sustainability is a multifaceted concept that strives to meet 'the needs of the present without compromising the ability of future generations to meet their own needs' (United Nations, 1987). It comprises multidimensional views and sustainable practices ranging from the technological to socio-political, economic and cultural endeavours. Having these plural significances, values or appeals gives the term a vagueness that can allow it to be turned into a motto emptied of its purpose. Thus, educators have a great task in integrating sustainable pedagogy into the existing curriculum. Recognising the above (and many other) challenges, this article focuses on teaching sustainability without flattening its complexity, totalising its concepts or emptying its creative potential. It seeks to determine the impact of an interior design/architecture studio experience that puts sustainability at the core of the way prospective graduates approach designing interior spaces.

\section{Towardls sustainable thinking}

It is well acknowledged that our planet is susceptible to catastrophic environmental events and that everybody should do their share of prevent- ing environmental and social degradation. Designers/architects can do much to prevent negative environmental consequences by adopting sustainable design practices. Because professional practices and behaviour are largely embedded in education and the precepts studied (Gürel \& Potthoff 2006), design education has an ethical responsibility to turn out environmentally conscious individuals who are sensible to social, cultural, economic, political, scientific and technological concerns and developments. Teaching sustainability requires first of all an understanding that sustainability is not a monolithic concept but a network of ideas. Even though these ideas may seem contradictory or opposing, as in the case of technological and ecological sustainability (Orr 1992, 24-5; Van Der Ryn and Cowan 2007, 20), they underscore the imperative need to save our planet [1]. On the one hand, this multidimensionality makes sustainability difficult to define and causes misconceptions; on the other, it fosters critical thinking, which helps maintain the vigilance to seek absolute truths. As the history of the built environment shows us, design prescriptions and totalising doctrines can impair critical thinking and result in misinterpretation and misuse. As examples, recent histories of modernism, characterised by universalist housing blocks that damaged people's relationships to their communities and urban renewal projects that spoiled traditional urban fabrics in the name of modernisation and development, remind us of the importance of avoiding oversimplifications, however moral a cause appears to be (Pyla 2008). Design education should recognise the potential in understanding sustainable development in its complexity and search for meaningful applications of sustainable design that cultivate a bond between human beings and their environment. This bond can be reinforced by meaningful relationships between design and people and by providing 'choices for people' (Papanek 1995).

There are many problems with incorporating sustainability into a curriculum that already covers many vital topics ranging from the history of the built environment to building systems and services. Sustainable design could be included as a
185

Meltem Ö. Gürel 
discrete course taught by experts who specialise in different areas of the field. However, it is questionable that this approach by itself would be an efficient way of integrating the topic into education; sustainability is a worldview that needs to induce consciousness about the way we think about our lifestyle, our behaviour and our relationship to our planet. As David Orr (1992) argued, awareness of sustainability is not value free; it involves an ethical position while maintaining objectivity in managing facts, data and logic. Teaching sustainability in a true sense means embracing this ethical position and understanding the significant role of the designer in rethinking lifestyles and encouraging sustainable behaviour through design (Lofthouse 2004; Stegall 2006). Adopting sustainable practices involves challenging the existing design culture and germinating radical ideas. These practices require full engagement with the sustainability agendas (Chick 2000). Thus, ideally, sustainability needs to be addressed in all topics of the curriculum by knowledgeable educators. This requires faculty at all levels and degrees of knowledge to educate themselves [2]. There is an abundance of venues available to educators to learn about the topic, including publications, conferences, workshops and the internet. Well-established organisations have been widely enthusiastic and active in taking a strong stance on sustainability and providing educational resources on the internet [3]. For example, the importance of sustainability in interior design education is endorsed by the International Interior Design Educators Council (n.d.) and the Council for Interior Design Accreditation (2006), which requires environmental ethics to be taught as part of professional values in credited programmes (Stieg 2006; Anderson et al. 2007). There are also emerging publications that focus on environmentally responsible interior design practices [4]. As interior design/architecture's principal intent is to ponder the creation of aesthetically pleasing spaces 'in order to enhance the quality of life and protect the health, safety and welfare of the public' in relationship to their environment (IFI 1983), this objective, in essence, encompasses the idea of sustainability.

A design studio can be an especially dynamic medium from which to have a strong position on, and test the productive potential of, sustainability. This is where design students can apply knowledge attained from coursework to a specific project. At its core, a design studio provides a discussion environment, beyond informational spoon-feeding. A studio project gives students opportunities to test their ideas and receive critiques both at philosophical and pragmatic levels. This interaction enables students to explore the creative potential of sustainability in shaping spaces and influencing the lifestyles that these spaces accommodate.

\section{Designing a studio experience}

Recognising this productive capacity of a studio course, an interior architecture project with a focus on sustainability was introduced in our undergraduate programme. The project was implemented as the graduation project for the duration of the nine-credit design studio during the second semester of the senior year [5]. The teaching of the studio at this level was not only intended to give a strong message prior to commencing professional life, but also required students to apply consolidated knowledge and curriculum subjects (such as space generation, construction, materials, lighting, furniture and building services) to the creation and development of an interior space with a focus on sustainability at a high capacity. The studio was instructed by a team of three instructors with varying degrees of knowledge in different aspects of the topic. Students received individual critiques from each instructor at regular intervals on a rotating basis. Reviews at the beginning, middle and end of the semester were conducted as a team. The teaching method aimed to reflect the dynamic and complex nature of sustainability by giving students the opportunity to be exposed to diverse viewpoints. Moreover, it was intended to serve as a medium to educate the faculty as well as the students. The instructors were involved in selfeducation through research, readings, lectures and, significantly, through discussions among the teaching group before and during the implementation of the studio.

Students were expected to become familiar with a great spectrum of sustainable concepts, 
including sustainable behaviour and living, environmentally, culturally and socially responsible design, adaptive reuse and revitalisation of old buildings in relation to an urban context, sustaining heritage (including cultural, architectural, industrial) and collective memory, sustainable development, sustainable design principles, green building/architecture/design, renewable resources, energy efficiency, ecological design, recycling, waste management, sustainable materials and construction methods, and water conservation and reuse. Simultaneously, they were encouraged to consider pitfalls of the term 'greenwashing', an expression introduced by environmental advocates referring to manipulations of sustainability in order to attract consumers. These topics were implemented through a variety of teaching tools.

First, the studio project was constructed to evoke issues of contextual connectedness. The way a design problem is defined can influence ways of conceiving solutions. In its philosophical premises, the problem was structured as an adaptable reuse project that embraced the sustainability philosophy by taking an extant small wine factory that was no longer in operation and reusing it by inserting new functions inside it. The socio-cultural context of the urban site as industrial heritage was considered in order to underscore the sustainability of collective memory.

Second, a number of experts in the field were invited to lecture on technological, ecological and social aspects of sustainability. These lectures aimed to educate the students as well as the instructors about the histories of sustainability and the environmental movement, major trends of global concern, sustainable development, inter-generational equity, basic principles of sustainability, unsustainable activities, how to measure sustainability, concepts such as the ecological footprint and life-cycle analysis (LCA), as well as socio-cultural concerns and the reuse and redevelopment of a building in its connection to the environment.

Third, students were asked to research different aspects of sustainability in teams and present their research to the class. Research topics highlighted sustainable principles, materials and technologies, case studies of environmentally respon-
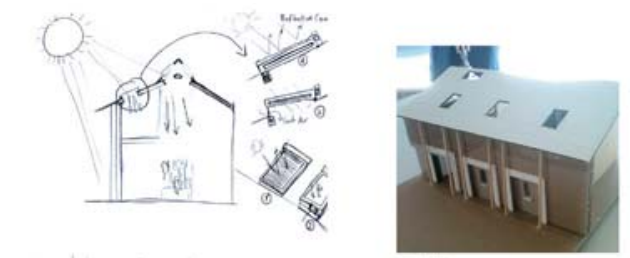

187

Meltem Ö. Gürel

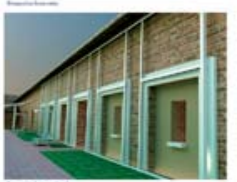

sible design projects, and the location, orientation and climatic conditions of the project site. A reading list, which included oft-cited books by design educators and internet sites of professional and benchmark organisations, were provided to help with the research [6].

Fourth, two major field trips were organised. One of these was to the model energy-efficiency building at the General Directorate of Electrical Power Resources Survey and Development Administration, where students learned about the capacity of solar energy and applications of energy conservation in building design. The second field trip was organised to the project site to analyse the factory building in its connection to the local, historical, architectural, urban and environmental contexts. During this field trip, the students were given an interactive lecture on the historical development and current conditions of the building and the revitalisation initiatives in the urban area. The lecture pondered the meaning of the building as industrial heritage, the socio-political position of the site in the larger urban context and the potential of sustaining the communal memory.

Fifth, individual desk critiques and group discussions of projects were implemented to move the students beyond the state of sustainable consciousness and to developing individual design approaches and refined design applications that emphasised the creative potential of sustainability. Students were asked to express and record their thought process through sketches, conceptual models/drawings and research documentation, which also constituted part of their final presentation and evaluation (Figure 1).
This page:

Figure 1

Presentation board showing Cansın Şengül's development of sustainable applications through sketches, study model and final drawing 
Finally, the studio itself was declared a 'sustainable environment', with the belief that our behaviour reflects our values and affects the way we think and produce. Recycling bins were located inside this and other studios and a corner was assigned to store scrap material/boards for reuse.

\section{Testing the studio experience: method}

The sustainable studio, which was initiated in spring 2008, was the first of its kind in our curriculum. The results of this studio experience were documented through a survey and observations that sought to determine how the teaching methods benefited the students and to what extent the approach impacted an interest in sustainable design. The main intention of the study is to help educators who are interested in incorporating and/or improving sustainable design education.

Students' responses to the project and the way they applied sustainable concepts were observed for a group of 39 students, and each student's design development and interventions were recorded on personal charts during individual critiques [7]. Along with notations on group discussions and reviews, this qualitative observation sought to evaluate not only students' inclinations in applying sustainable design but also the quality of their applications.

Questionnaires were electronically mailed in January 2009 to 47 graduates of the spring 2008 studio whose email addresses could be found. The aim was to find out the views of the graduates after they had had an opportunity to experience the field and evaluate their education. The first set of questions acquired background information from the individuals. They were asked how important they thought sustainability was to design/architecture education and in what capacity they knew about the topic prior to the course. The questionnaire asked the individuals to evaluate their answers on a scale of 1-5.

The second set of questions sought to determine specific information about the studio experience: (1) to what extent taking the sustainable design studio stimulated their interest in the subject; (2) to what extent taking the sustainable design studio made a difference in the way they approached design; (3) in their experience, which instruction method most helped them to learn about sustainability and which teaching method most facilitated developing creative design solutions; and (4) how well the studio helped them to apply sustainable design concepts to a project.

The third section asked specific questions about the student's project: (1) how well the student was able to incorporate sustainable design into their design project; (2) which aspects of sustainability the individual most emphasised in their project; (3) to what extent this project helped them understand sustainability as a multidimensional concept that requires critical thinking.

The fourth set of questions inquired if the students wished more exposure to sustainability and if so, how best to include sustainability in the curriculum (e.g. teaching method and level of instruction). Finally, the graduates were asked the ways in which taking this course helped them after graduation and were invited to share any additional comments that they might have.

\section{Findings}

\section{Observation and evaluation of the students' approaches}

Initially, students widely felt obliged to adopt high levels of technology in their projects and carried out extensive research on new sustainable technologies. Some 64 per cent of the students interpreted sustainable design as the insertion of these technologies, such as photovoltaic panels, wind turbines, geothermal heating, and use of innovative or recycled materials. Students assumed that technology could undo the wrongdoings of human beings to the environment (also shown by a study by Ruff \& Olson 2009). Some students inclined to invest most of their time in designing technologies and equipment for which neither they nor the instructors had the training and skills. This is partly because they felt that these were more noticeable manifestations of sustainable design, which helped them to be successful in the studio. Prominence of technoscientific approaches in the existing literature and the internet are other reasons for this inclination, which matured through our teaching strategy during the semester. In the second half of the 


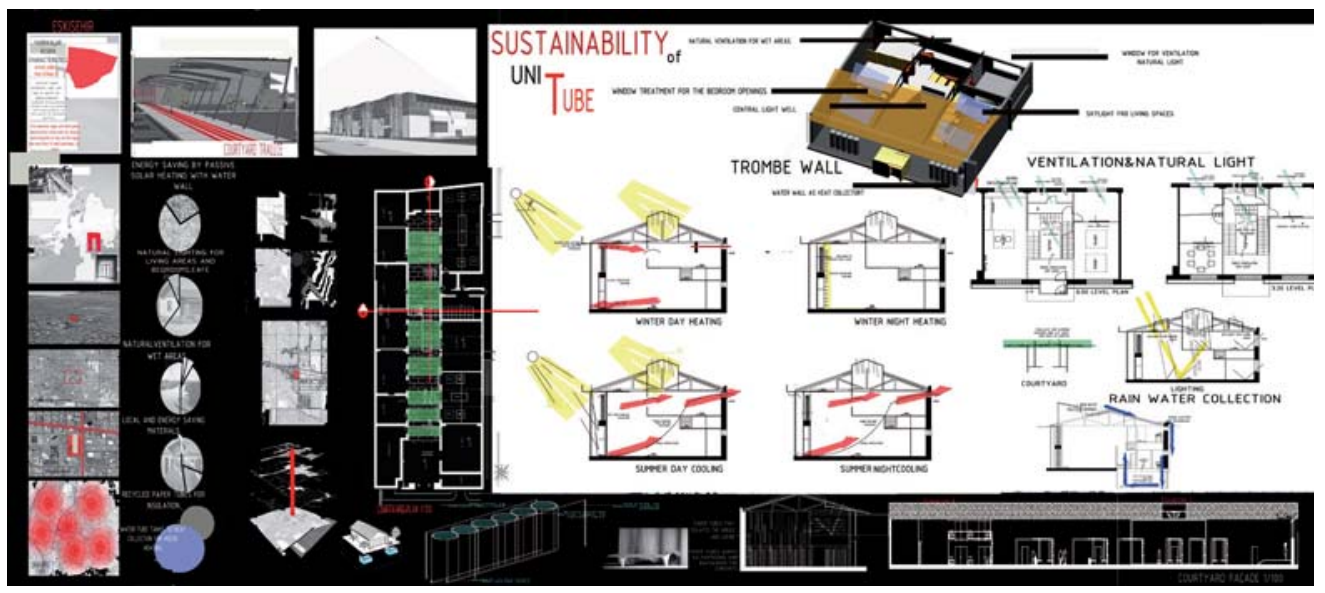

189

Meltem Ö. Gürel

ARAL CDURT

$1 / 2$

\title{
SUSTAINABILITY HOUSE: guest house for scholars
}

\begin{abstract}
IN TODAY'S WORLD EFFICIENT USAGE OF NATURAL RESQURCES IS COMPULSORY. LIMITED RESIURCES AND MAINTENANCE COST OBLIGE THE DESIGNER TD THINK ABQUT THE SUSTAINABLE DESIGN CRITERIA.

BESIDES NEW BUILDINGS, SUSTAINABLE DESIGN CRITERIA SHOULD BE CONSIDERED IN THE RENOVATION AND ADAPTIVE REUSE OF EXISTING BUILDINGS.
\end{abstract}

\section{LIGHT·WELL PROPERTIES:}

1) CHANGE IN THE RODF SLOPE AT THE SOUTH SIDE PROVIDES THE APPROPRIATE ANGLE FOR THE MAXIMUM PERFORMANCE OF SOLAR PANELS IFOR THE PROJECT'S LOCATION THIS IS $4 D^{\circ}$ )

2) CHANGE IN THE ROOF SLOPE PROVIDES EXTRA ATTIC SPACE FOR HOT WATER STORAGE, SOLAR PANEL EQUIPMENT AND AN DPENING FOR DAYLIGHT \& VENTILATION FLUE.

3) PLACEMENT OF THE LIGHT-WELLS AT THE DARK AREAS IN THE MIDDLE AND AT THE PERIPHERY PROVIDES NATURAL LISHT AND VENTILATION FOR EACH ROOM AND THE ATRIUM.

4) VENTILATION PROVIDES A FUNCTIONAL AREA TO DRY THE LAUNDRY

5) USE OF LED LIGHTING IN THE LIGHT-WELL CREATES AN ARTISTIC SPACE.

SUSTAINABLE CONSIDERATIQNS:

DESIBN OF A COMPATIBLE CONSTRUCTION SYSTEM WITH A MULTIFUNCTIONAL APPROACH AND CHOICE OF LOCALARECYCLEOEECONOMIC MATERIALS. (i)

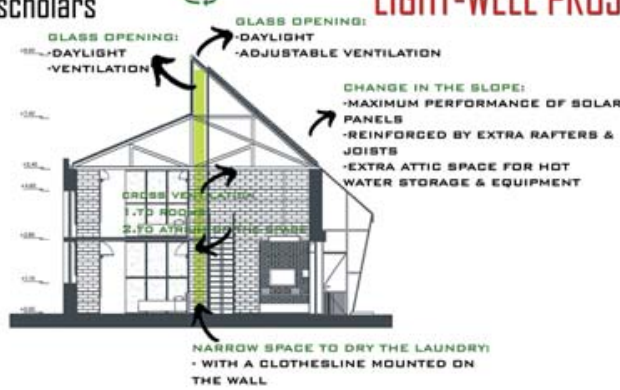

LIGHT-WELL PRDJECT:
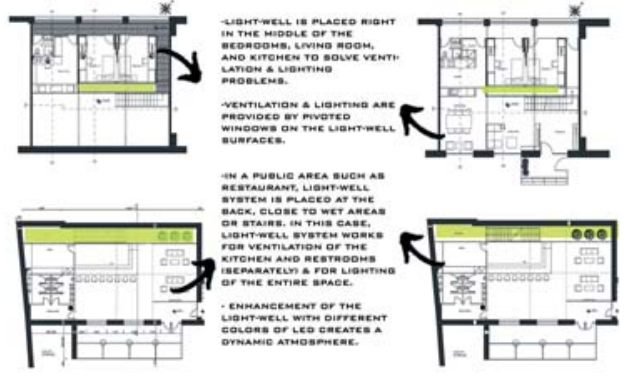

course, students largely learned to develop spatial solutions with regards to the contextual setting - environmental, climatic, local, sociocultural and economic constraints. They came to search for ways of reducing the use of electricity, integrating passive solar designs and reducing heat gain in resolving spatial allocations and three-dimensional development of space. In addition to advanced green technologies, students were urged to utilise spatial articulations and physical applications in order to design for energy efficiency, maximise the use of diffused and uniform natural light, and improve indoor air quality through natural ventilation and orientation of openings (i.e. windows, doors and skylights) (Figure 2). These applications included unique interpretations of architectural elements such as a Trombe wall (or thermal mass), wind catchers, light shelves, light tubes and shading devices, as well as common design components such as
This page:

Figure 2

Semra Horuz's concept board showing a study of the location, materials, use of green technologies and physical applications in order to design for energy efficiency, maximise the use of natural light, and improve indoor air quality through natural ventilation and orientation of openings.

Figure 3

Ekin Kömürcü's spatial interventions maximising the use of natural light and ventilation while regarding the existing architectural elements (loadbearing walls and trusses) and connection with the past. 
190

Meltem Ö. Gürel
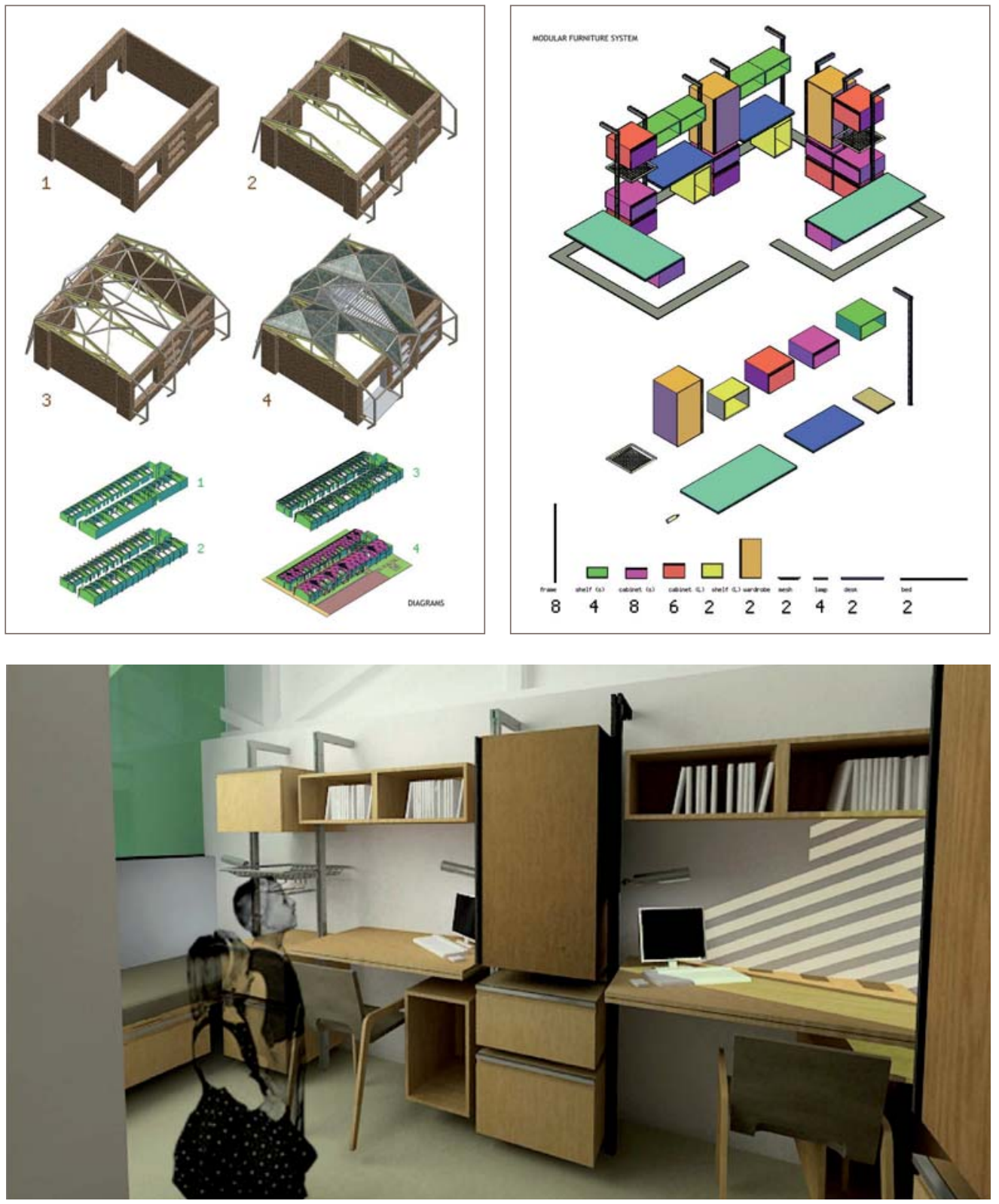

window treatments articulated according to the orientation (north, south, east, west) and character of light (horizontal, vertical). Notably, students had foundational knowledge of physical applications from their lecture courses, such as building services, however, they were inclined to underestimate their potential as sustainable applications and required great help in realising and detailing such applications in their projects.
In the beginning of the semester, students were drawn to new materials and technologies that they found on the internet. This approach brought out the concern, followed by discussions, about the use of the internet. While the internet is a valuable and convenient resource for searching for information, students tended to assume that its information was reliable and accurate, without questioning the source. The students' widespread belief 
that in order to create sustainable solutions they needed to use innovative materials produced by new technologies ignited discussions on the benefits of using local materials, drawbacks of material production techniques (for example, energy waste and toxin outputs), and the value of embracing a 'cradle-to-cradle' philosophy, that suggests the sustainable management of waste, as opposed to a 'cradle-to-grave' approach, where the use of a material terminates in a type of material grave (McDonough \& Braungart 2002). The possibility of restoring and/or reusing existing materials/elements became an important consideration not only in reducing consumption and construction cost, but also in sustaining the architectural, cultural and social positions of the structure and the collective memory. For example, students' spatial interventions to maximise the use of natural light and ventilation took into account existing architectural elements, such as trusses, and historic or local connections (Figure 3). Even those who were inclined to disregard fully the existing when emphasising techno-scientific dimensions were reminded of these concepts during the discussions.

Materials use also brought out a concern about greenwashing and the need for critical thinking in calculating the advantages of a particular material. For example, although bamboo is an environmentally sensible material because it grows quickly, the use of bamboo flooring should be re-evaluated with regards to transportation. Students had notable difficulty in adopting sustainable ideas for selecting and designing built-in and freestanding furniture and finishes. They were inclined to appraise furniture on the basis of stylistic- and form-related concerns. Emphases on appearance and ergonomics were balanced with considerations of the use of sustainable materials and building techniques, maintenance, life cycle, and the primacy of a concern for reducing, reusing and recycling throughout the semester (Figure 4).

\section{Survey}

Forty-two graduates (90 per cent) completed and emailed back the questionnaires. All the respondents thought that sustainable design was important to interior design/architecture education: 47
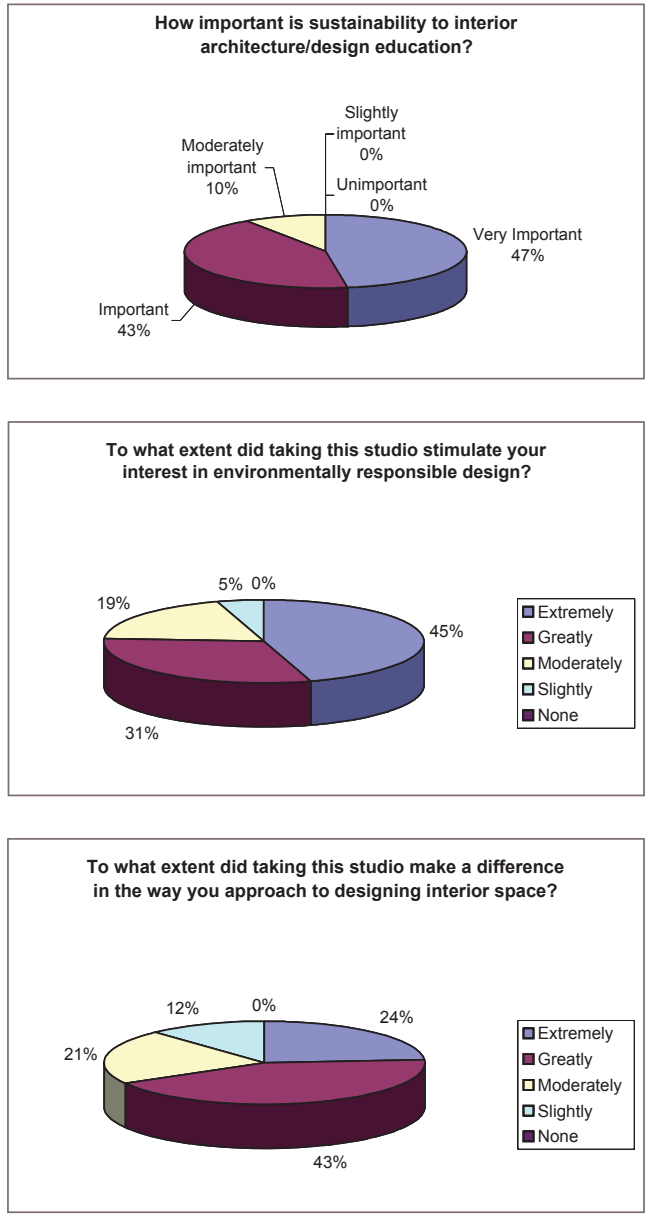

per cent thought it very important, 43 per cent important and 10 per cent moderately important (Figure 5). The survey showed that before students took the studio course they had varying degrees of knowledge in sustainable design. However, even when they were familiar with concepts of sustainability, they had very limited knowledge about how it could be applied to interior design/architecture.

In response to the specific questions about the studio experience, all of the graduates agreed that having to apply sustainable design principles to their projects stimulated their interest in environmentally responsible design (Figure 6). The average of this interest was 4.17 on a 5.00 scale. The survey showed that taking the studio made a considerable difference in the way this group approached designing interior space in general (Figure 7). The internet was thought to be the
191

Meltem Ö. Gürel

Opposite page:

Figure 4. $(a, b, c)$ Yigit Kale's project utilises modular systems both in building and furniture design. Every primary component is transformable, repeatable and replaceable. To minimise waste, modular furniture system takes into consideration the manufacturing sizes of plywood. Building design takes advantage of the industrial site by using scrap materials from the inactive plants. Concept diagram shows the pattern of the exterior cladding, green terraces and vents generated in relation with the original structural system of the building .

This page:

Figure 5 Students' responses to how important sustainability is to interior architecture/ design education.

Figure 6

Chart displays, in percentages, the extent that taking this studio stimulated interest in environmentally responsible design.

Figure 7

Chart displays how much of a difference taking the sustainable design studio affected the way the graduate would approach interior architecture/design. 
most helpful way to learn about sustainability (76 per cent). This was followed by guest lecturers (57 per cent), literature research (55 per cent) and studio critiques (55 per cent) (Figure 8). The teaching methods that most helped students to develop creative solutions to environmentally and socially responsible design were studio critiques (62 per cent) and internet research (60 per cent) (Figure 9). In general, the graduates largely felt that the studio helped them to understand how they could apply sustainable design concepts to a project regardless of how well they performed in the studio (Figure 10).

Responses to specific questions about the graduates' projects indicated that the most-emphasised aspects of sustainability were use of natural light (4.43 on a 5.00 scale), development of space according to sustainable considerations (4.40), design for energy efficiency (4.33), use of renewable energy (4.14) and use of materials/finishes (4.10)(Figure 11). Nonetheless, as the chart shows, a wide spectrum of sustainable topics and solutions was considered. This evaluation suggests that the teaching scheme helped students recognise sustainability as a multidimensional concept

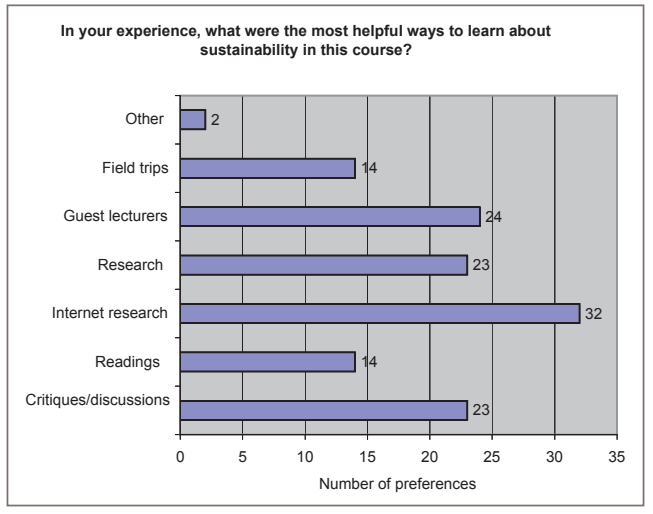

Which teaching methods most helped you to develop creative solutions to environmentally responsible design?

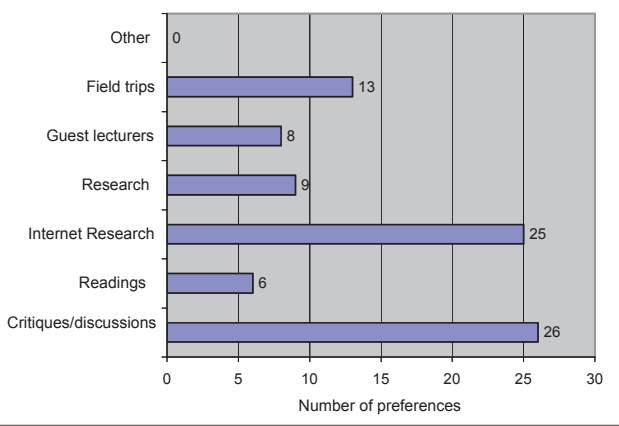

\section{Whether you were successful or not in this project, how much do you think that taking this studio developed your understanding of how to apply sustainable design concepts to an interior design project in general?}

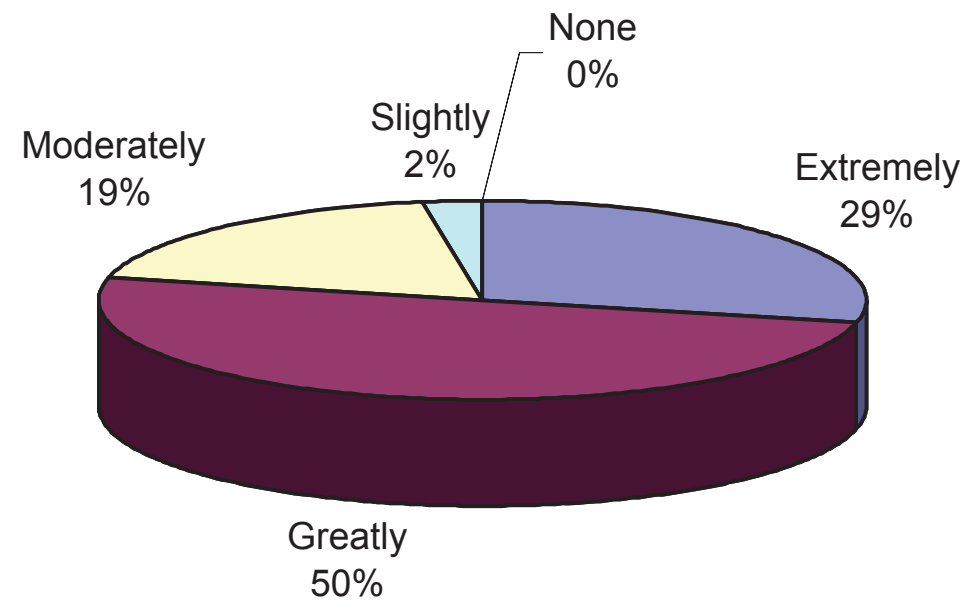




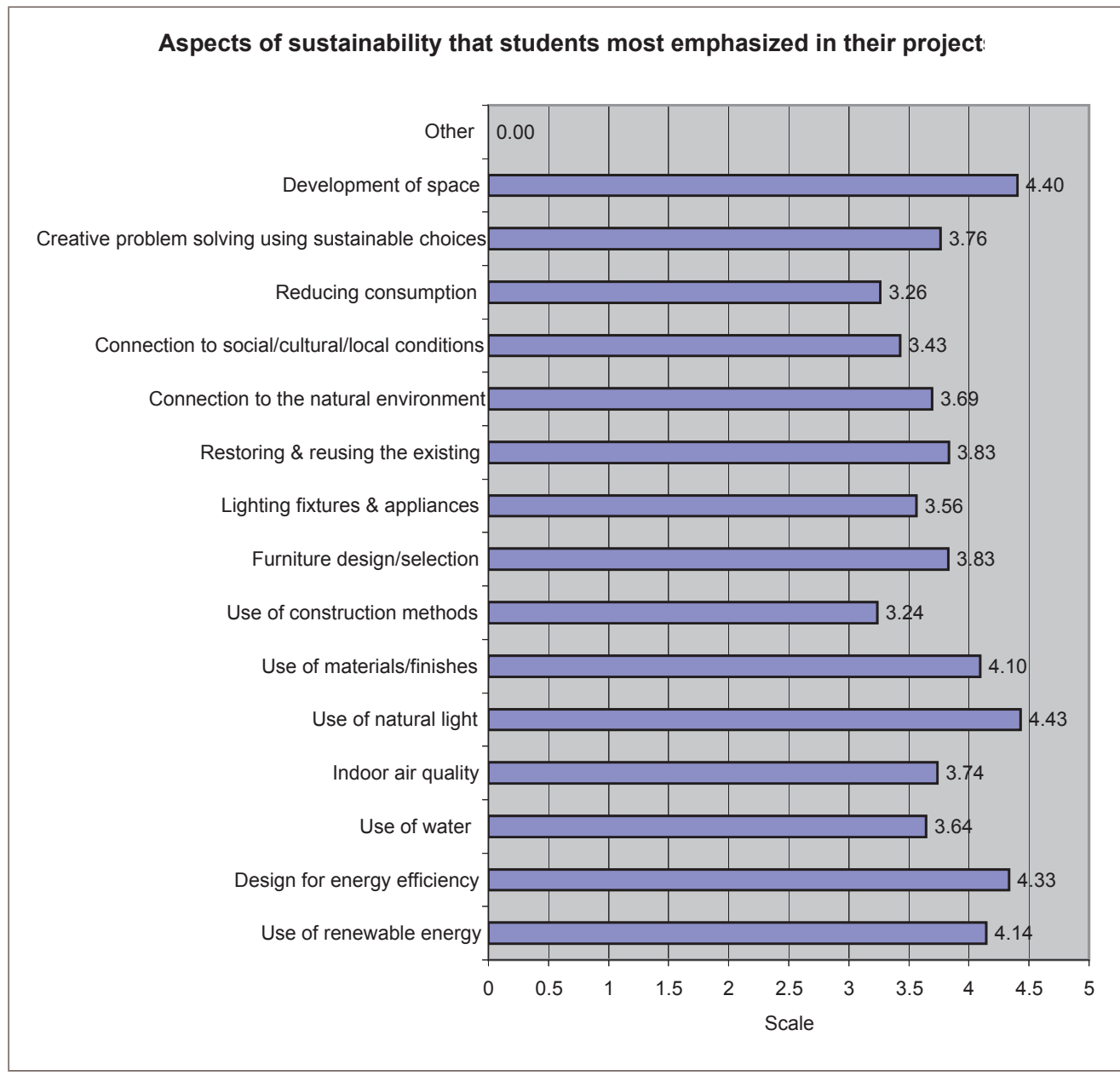

\section{To what extent did this project help you understand sustainability as a multidimensional concept that requires critical thinking?}

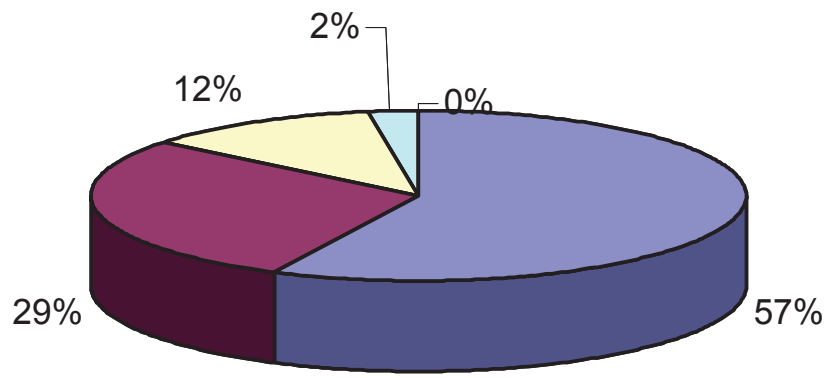

\begin{tabular}{l}
\hline Extremely \\
$\square$ Greatly \\
$\square$ Moderately \\
$\square$ Slightly \\
$\square$ None
\end{tabular}

193

Meltem Ö. Gürel

Opposite page:

Figure 8

The most-helpful ways to learn about sustainability in this course, according to the students.

Figure 9

Teaching methods that most helped the students to develop creative design solutions of environmentally responsible design

Figure 10

Students' responses to how much this studio developed their understanding of how to apply sustainable design concepts to an interior design project, regardless of their success in the project.

This page:

Figure 11

Aspects of sustainability that students most emphasized in their project.

Figure 12

Students' assessment of the value of this studio in comprehending sustainability as a multidimensional and complex concept that requires critical thinking. 


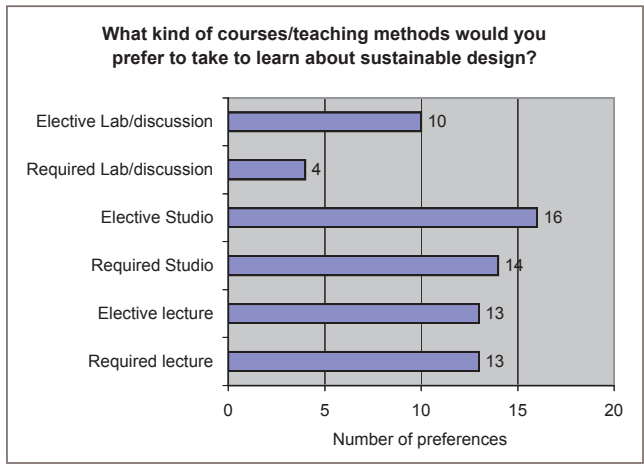

In your opinion, should sustainability be integrated into curricular courses?
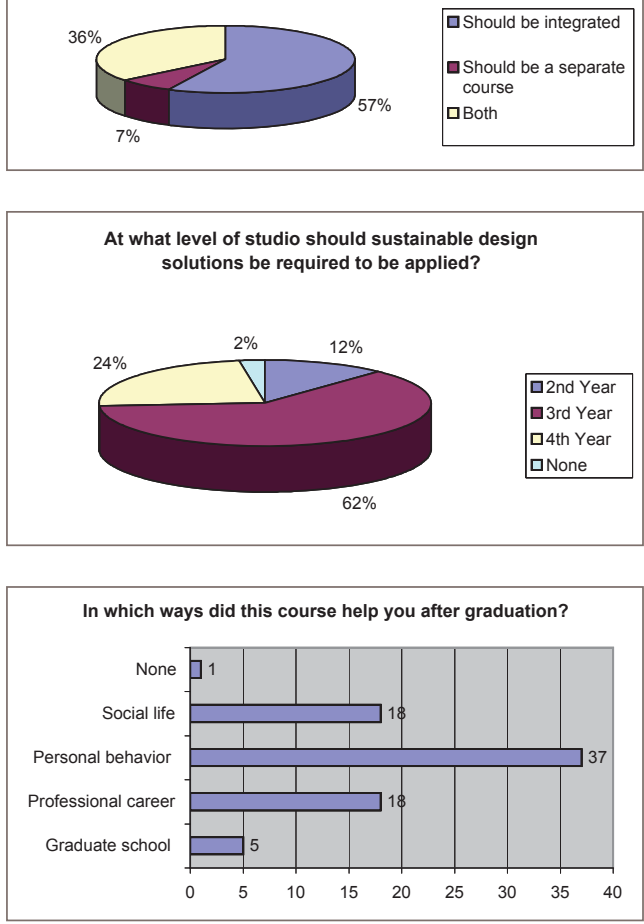

that requires critical thinking. Also reflecting this comprehension were the graduates' responses to the question that inquired about the extent to which they understood the significance of this plurality and complexity: 57 per cent of the graduates understood very strongly, 29 per cent strongly, 12 per cent moderately and 2 per cent slightly felt that the studio experience helped them to comprehend the analytical thought process required to deal with this complexity (Figure 12).
Of the recent graduates, 98 per cent indicated that they would be interested in more courses on sustainability if the programme offered them. Students' preferences of course types and teaching methods varied (Figure 13). By and large, the group thought that sustainability should either be integrated into existing courses (57 per cent) or both be integrated and offered as separate courses (36 per cent). Only three students (7 per cent) thought that sustainability should only be offered as a separate course (Figure 14). Some 62 per cent of the students thought that the junior year would be the most appropriate level for a required sustainable design studio, while 24 per cent thought the level to be the senior year and 12 per cent the sophomore year. One student (2 per cent) felt that a sustainable design studio should not be required (Figure 15). In their written comments, some graduates felt that more exposure to sustainable design should be implemented in earlier stages of the curriculum. In the survey, 58 per cent of the graduates indicated that they had learned little or nothing about the topic in other curriculum courses. Their comments indicated that this inadequacy of exposure and foundational knowledge made it difficult for them simultaneously to learn and apply sustainable design. As one individual put it: 'Although we had many lectures, guest lecturers, research, readings and critiques/discussions [in this course], it should be accepted that sustainability is a wide ranging subject and it requires a comprehensive background.' Even though this was a nine-credit course, one semester or a single course did not appear to be sufficient to cover the subject.

Despite the limited instruction on sustainability, the studio experience seemed to have graduated environmentally conscientious individuals who seek to apply sustainable design concepts in all aspects of life; according to the responses, the studio course helped graduates in personal behaviour (88 per cent), social life (43 per cent), professional career (43 per cent) and/or graduate school (11 per cent) (Figure 16). In their written comments, some students reported the difficulty of applying sustainable design in professional life. On the other hand, some reported that the 
studio in fact helped them to find a job. One student wrote, 'Sustainability is so important that it helped me to advance in my current job. I was singled out.' Another student, who is currently working on sustainable hotel projects in BarceIona, responded, 'I shared the (interior) architectural solutions that we designed. People here were very surprised that we developed unique designs for our project instead of using readydesigned systems.'

Graduates who shared their comments overwhelmingly expressed an appreciation for the opportunity the studio experience provided them. They considered themselves lucky to have been able to take the studio. Notably, they also expressed a disappointment for not being sufficiently exposed to topics of sustainability in our programme prior to the studio. One graduate stated that, 'I was not totally aware of sustainability in its relation to designing interior space until I took the fourth year design studio.' As another individual put it, 'I realised the whole world, everybody, was talking about sustainability only after I took this studio.' These remarks are fine examples of how selective perception works. They indicate the role of education in conceiving the significance of sustainability and bring out the question whether one studio was sufficient, without more foundational knowledge having been attained in earlier years of the programme.

\section{Analysis of the project: successes and failures of the scheme}

A pedagogical objective of the studio was to provide a learning environment that cultivated multivalency of sustainability by constructing a balance between its technological and social ends. At the initial stage, structuring diverse lectures delivered by experts from different backgrounds and disciplines, organising dissimilar field trips, and assigning research teams a range of subjects helped to construct the intended balance and convey the multidimensional as well as the interdisciplinary disposition of sustainability. These activities encouraged critical thinking by connecting the students with information that would need to be processed to construct a meaning in response to the problem, which embodied many solutions (Adams \& Hamm 1994). Moreover, they allowed the learners to bond with each other and with the view that sustainable living is as much an ethical issue as it is a technical one (Fox 2000). In other words, the teaching method contributed to the development of a subjective position in recognising sustainability as a worldview that can make a difference in our everyday relationship with the world. To this end, these activities were useful in incorporating objectivity with a strong value point of reference (Orr 1992).

Among these activities, carrying out and presenting research in teams appeared to be very effective in establishing, as one student pointed out, the value in becoming not only accountable designers but also sensible global citizens. Through interaction, the teamwork mediated cooperative learning as well as bonding. Lectures was the method least preferred by the students. Conventional lectures in a classroom, where students are passive learners, can be less productive because the level of concentration substantially drops during the duration of the instruction (Ali 2005; Smith et al. 2009). After the second lecture, we observed that some students lost interest in getting information in the lecture format. At this point, utilising field trips supported by interactive lectures (shorter explanations supported by questions and answers) outside of the classroom appeared to be successful because they facilitated student engagement. For example, students' interaction with construction materials, such as feeling the temperature difference on insulated and non-insulated glass, playing with energy-efficient light bulbs, examining an actual application of a Trombe wall, or experiencing enhancement of natural light through skylight designs at the model energyefficiency building maximised learning by engaging the students as active participants. Likewise, seeing and experiencing the interior and exterior spaces of the actual project building in connection to the environmental, historical and social contexts while being informed about its local, urban, architectural and communal meaning by local inhabitants and scholars aroused interest in sustainable development in its dependence on culturally marked values. Students were able to
195

Meltem Ö. Gürel

Opposite page:

Figure 13

Students' preferences for courses/ teaching methods for learning about sustainable design

Figure 14

Students' preferences for incorporating sustainability into the curriculum.

Figure 15

Students' prefer-

ences for the level of studio in which sustainable design solutions should be required to be applied.

Figure 16 Ways in which this course helped students after graduationln. 
evaluate the environment within the larger cultural and temporal contexts and to understand that the history of a place influences our perception, which can itself change over time. This motivated many students to construct the design problem as a culture-bound space in relationship to the environmental setting rather than a value-free space (Moser 2003, 3).

A major problem with the sustainable studio was the students' (mis)conception of sustainable design as primarily a technological problem to be resolved by scientific means alone. A balanced structure of field trips, lectures and group research at the initial stages contributed to overcome this conception. The construction of the project was effective in setting the stage for the socio-cultural content of sustainability; such an activity can inform the thought process and shape the design. Yet, these methods were not adequate in reconstructing the notion of sustainable design for the average student and opening minds about its relationship to design at all levels. Our teaching method, which conceptualises the design studio as a centre of communication for students and instructors where they reflect each other's actions (Schön 1984; Wender \& Roger 1995), was the main tool used to challenge this thinking. The studio cultivates layers of information mediated in many ways - orally, graphically, verbally, behaviourally and so on - through interaction among the users, all of whom can learn from each other.

A major learning advantage of the method for students is that they are engaged with diverse meanings and practices of sustainability through a wide spectrum of design critiques and discussions, ranging from scientific applications to sustaining industrial heritage, via instructors with different training, competence levels and orientation toward sustainability. This dynamism and diversity give the students opportunities to develop critical thinking skills and discourage using decisive templates to achieve solutions. The outcome of the studio showed that students were largely successful in searching for and producing a variety of design solutions and applications that used sustainable choices. The survey indicated the multiplicity in how students empha- sised sustainability in their design projects (Figure 11). Hence, the scheme proved to convey the philosophical stance that sustainability is a pluralistic and intricate concept that requires a critical thinking process.

A practical aspect of this system with regard to learning and teaching is that the studio becomes an active and lively learning ground, rich in (counter-)discussions not only for students, but also for the teaching team. Teamwork is frequently preferred in tackling complex problems and activities because it brings together individuals who may have different knowledge and skills (Lee 2007). Therefore, teamwork has the potential to function as a productive learning environment where members can exchange and share their knowledge, skills and ideas, and where they can challenge certain constructs and see the problem through different lenses. As an instructor and coordinator of this project, I observed that all the instructors have learned from each other and have been inspired by others' enthusiasm, cooperation and intellectual rigor towards sustainability throughout the semester. On a personal note, I have tremendously benefited from the competence of a very knowledgeable colleague, who has had scientific training, in applying practical techniques of sustainability. The interaction among the teaching team enriched each instructor's competence and vision of sustainability. This maximised learning/teaching environment inevitably benefited the students of the study semester and students since.

Observations and the survey showed that this scheme was successful, to a great extent, for teaching and learning the value and creative potential of sustainability in shaping spaces and influencing behaviour in the senior-level studio. However, it may not always be easy or possible to bring together design instructors with diverse and complementary backgrounds who can collaborate harmoniously. This major difficulty can be addressed at an administrative level. Another drawback is that students may be subject to tension between techno-scientific and socio-cultural dimensions. Therefore, this system works best at higher studio levels when students have acquired a broad and consolidated knowl- 
edge and competence of skills that enables a mature position from which to tackle the complexity of the design problem and the dynamics of the studio. Moreover, as the students' comments suggested, foundational knowledge of sustainability attained at lower levels would improve the effectiveness of this scheme.

\section{Conclusion}

This study revealed that graduates recognise environmentally responsible design as an imperative that needs to be included in education. A studio experience and design pedagogy that puts sustainability at its core generally makes a difference in the way students understand and approach design. The findings also suggested that sustainability is larger than a single course offered in a single semester, however dense and involved that course may be. Ideally, sustainability should be woven into every aspect of a curriculum in order to achieve a thinking that shapes the way prospective designers process information and adopt environmental consciousness.

What made this studio unique was the fact that it was the first in our programme that not only aimed to teach sustainable design concepts through implementing a variety of teaching methods, but also required refined design applications that used sustainable choices. A teaching scheme that mediated the education of instructors with varying degrees of knowledge in different aspects of the topic and the students enabled a productive environment in which to address and emphasise a variety of viewpoints and a wide range of concepts. The teaching pedagogy underlined that sustainability is not a singular concept and that there are no fixed referents of the term, hence encouraging the seniors to analytically think and critically question any given information rather than taking it as fact.

The evaluation of the design studio suggests that students largely appreciated this plurality after graduation even if they struggled in incorporating sustainable design in their projects when they took the course. Some loudly criticised their initial approaches and felt that inadequacy of exposure to concepts of sustainability in their previous courses caused them to lose valuable design time in developing the project. They later noted that since completing the studio learning process, they tackle projects more thoughtfully. While the results of the survey show that the studio was effective in educating and influencing the views of the graduates about the significance of environmentally responsible design, it showed the need to review and revise the existing curriculum to include sustainable design concepts. An efficient way of doing this may be to update the content of each lecture course to address environmentally conscious choices. For example, a lighting-design course may emphasise the use of natural light and design for energy efficiency to a greater extent by underlining the impact of these on sustainable development. A small project or assignment may help to absorb this emphasis. Arguably, such an intervention would better equip students for a studio experience that ponders creative problem-solving emphasising sustainable concepts and choices.

A valid question is if or when to teach a studio with a focus on sustainable design applications. The graduates' responses suggested that although concepts of sustainability should be introduced as early as possible as an imperative part of the design field, a required studio should be introduced in the third (62 per cent) or fourth (24 per cent) years. These comments indicate that students are also aware that meaningful application of sustainable concepts to a design project requires attaining broad knowledge in their field and developing critical lenses through which they can evaluate pitfalls of sustainability. At higher studio levels, after students attain consolidated knowledge in topics of curricula (including sustainability) and are more competent in designing more complex spatial problems, they are more prepared to develop refined and detailed solutions for environmentally responsible design. It is important to recognise that 'sustainability' is a vague term, susceptible to misinterpretation, misconception, misuse and even abuse. Educators need to guard against reducing the term to a keyword emptied of its intricacy and real meaning in the body of a design project. This study hopes to give a perspective for integrating sustainability into interior design/architecture education while arguing that
197

Meltem Ö. Gürel 
students need to be exposed to this intricacy. What makes the concept of sustainability so sustainable is that there is an urgent need for socially and environmentally responsible design, but there is not an absolute way or a totalising concept in creating sustainable design solutions.

\section{Acknowledgements}

I would like to thank all my colleagues, and especially the studio instructors Alper Küçük, Murat Özdamar, Elif E. Türkkan, Sibel E. Ural and Cengiz Yener, who contributed to the implementation of the first sustainable design studio in our curriculum. I would especially like to recognise the late Dr Cengiz Yener, from whom I have learned so much about the techniques of sustainable applications.

\section{Notes}

1. As noted by David W. Orr (1992, 24-5), technological sustainability suggests that 'every problem has either a technological answer or a market solution. There are no dilemmas to be avoided, no domains where angels fear to tread.' Ecological sustainability, on the other hand, refers to 'the task of finding alternatives to the practices that got us into trouble in the first place; it is necessary to rethink agriculture, shelter, energy use, urban design, transportation, economics, community patterns, resource use, forestry, the importance of wilderness, and our central values' (Van Der Ryn \& Cowan 2007, 20).

2. This relates to the argument that environmental education should be considered at all levels (Palmer 1998).

3. Some of these organisations include: The Interior Design Educators Council (IDEC)'s Green Design Education Initiative (http://www.idec.org/ greendesign/home.html); the International Interior Design Association (IIDA)'s Knowledge Centre (http://knowledgecenter.iida.org/); American Institute of Architects, the Committee on the Environment (COTE) (http://www.aia.org); and the US Green Building Council (the Leadership in Energy and Environmental Design (LEED), http://www.usgbc.org).
4. Recent additions include Jones (2008) and Winchip (2007).

5. A regular design studio is six credits in our interior architecture programme.

6. Notably, books listed on the American Society of Interior Designers (ASID)'s web page were a great resource for our students.

7. The studio had two sections taught by six instructors. Each section had 39 students and three instructors.

\section{References}

Adams, D. \& Hamm, Mary. (1994) New Designs for Teaching and Learning: Promoting Active Learning in Tomorrow's Schools. San Francisco: Jossey-Bass

Ali, S. (2005) Effective teaching pedagogies for undergraduate computer science, Mathematics and Computer Education, Vol. 39, No. 3, pp. 243-58

Anderson, B. G., Honey, P. L. \& Dudek, M. T. (2007) Interior design's social compact: key to the quest for professional status, Journal of Interior Design, Vol. 33, No. 2. pp. v-xiii

Chick, A. (2000) Preparing British design undergraduates for the challenge of sustainable development, International Journal of Art \& Design Education, Vol. 19, No. 2, pp. 161-9 Council for Interior Design Accreditation (2006) accreditation manual (online). Available from URL: accredit-id.org/accredmanual.pdf (accessed 29 May 2009)

Fox, W. (2000) Ethics and the Built Environment. New York: Routledge

Fuller, R. B. (1969, repr. 2008) Operating Manual for Spaceship Earth. Baden, Switzerland: Lars Müller Publishers

Gürel, M. Ö. \& Potthoff J. K. (2006) Interior design in architectural education, International Journal of Art \& Design Education, Vol. 25,

No. 2, pp. 217-30 
Interior Design Educators Council (n.d.) IDEC 2005 Annual Report. Indianapolis, IN

International Federation of Interior Architects/ Designers (1983) General Assembly, Definition of an interior architect/designer (online).

Available from URL: www. ifiworld.org (accessed 5 January 2009)

Jones, L. [Ed.] (2008) Environmentally Responsible Design: Green and Sustainable Design for Interior Designers. Hoboken, $\mathrm{NJ}$ : Wiley

Lee, K. C. K. \& Cassidy, T. (2007) Principles of design leadership for industrial design teams in Taiwan, Design Studies, Vol. 28, No. 4, pp. 437-62

Lofthouse, V. (2004) Investigation into the role of core industrial designers in ecodesign projects, Design Studies, Vol. 25, No. 2, pp. 215-27

McDonough, W. \& Braungart, M. (2002) Cradle to Cradle: Remaking the Way We Make Things. New York: North Point Press

Moser, G. (2003) Sustainability, people and places: an agenda for the future, in Moser, G., Pol, E., Bernard Y., Bonnes, M., Corraliza, J. A. \& Giuliani, M. V. [Eds] People Places and Sustainability. Seattle: Hogrefe \& Huber, pp. 1-6

Orr, D. W. (1992) Ecological Literacy: Education and the Transition to a Post-modern World. Albany: State University of New York Press Palmer, J. (1998) Environmental Education in the 21st Century: Theory, Practice, Progress and Promise. London and New York: Routledge Papanek, V. (1995) The Green Imperative: Natural Design for the Real World. New York: Thames and Hudson

Pyla, P. (2008) Counter-histories of sustainability (online). Available from URL: www.archis.org/ volume/2008/00/00/Counter-Histories + of + Sust ainability/7619 (accessed 15 January 2009)
Ruff, C. L. \& Olson, M. A. (2009) The attitudes of interior design students towards sustainability, International Journal of Technology and Design Education, Vol. 19, No. 1, pp. 68-77

Schön, D. A. (1984) The architectural studio as an exemplar of education for reflection-in-action, Journal of Architectural Education, Vol. 38, No. 1, pp. 2-9

Smith, D., Hedley, P. \& Molloy, M. (2009) Design learning: a reflective model, Design Studies, Vol. 30, No. 1, pp. 13-37

Stegall, N. (2006) Designing for sustainability: a philosophy for ecologically intentional design, Design Issues, Vol. 22, No. 2, pp. 56-63

Stieg, C. (2006) The sustainability gap, Journal of Interior Design, Vol. 32, No. 1, pp. vii-xxi

United Nations (1987) Report of the World Commission on Environment and Development, 42/187, 96th plenary meeting, 11 December (online). Available from URL: 209.85.129.132/ search?q=cache:vpJ1SixhEGUJ:www.un.org/ documents/ga/res/42/ares42-187.htm+Meetin $\mathrm{g}+$ the + needs + of + the + present + without + co mpromising + the + ability + of + future + generati ons + to + meet + their + own + needschl $=$ trgct $=$ clnk\&cd $=2 \& g \mid=\operatorname{tr}$ (accessed 10 February 2008)

Van Der Ryn, S. \& Cowan, S. (2007) Ecological Design. Washington, DC: Island Press

Wender, W. V. \& Roger, J. (1995) The design life space: verbal communication in the architectural design studio, Journal of Architectural and Planning Research, Vol. 12, pp. 319-36

Winchip, S. M. (2007) Sustainable Design for Interior Environments. New York: Fairchild Publications 